\title{
Synthesis of Nonclassical Quinazolinone Antifolates as Thymidylate Synthase Inhibitors and Their Antitumor Activity In Vitro
}

\author{
Du-Jong Baek, ${ }^{*}$ Tae-Beom Kang, and Hyun Ju Kimं \\ Deparment of Chemistry, College of Natural Science. Sangmwng Chiversin. Seoul 110-743. Korea \\ Research Laboratory, $R$ \& D Division, Choongwae Phama Co., Sum $4+45-976$, Korea \\ Received.tugust 17, 2004
}

\begin{abstract}
Nonclassical quinazolinone analogs I, II, and III, in which the glutamic acid moiety of the classical antifolates is substituted by pheny lglycine. pheny lalanine or aminobenzoic acid and their methyl esters, were synthesized and evaluated as lipophilic inhibitors of thymidylate synthase (TS). The target compounds were generally potent inhibitors of $L$. casei and human TS with $\mathrm{IC}_{3 i}$ values within the narrow range of $0.2-10 \mu \mathrm{M}$ and 0.003 $0.03 \mu \mathrm{M}$. respectively. Further. most of the target compounds showed cytotoxicity against tumor cell lines of murine and human origin with $\mathrm{IC}_{s i}$ values of as low as $0.050 \mu \mathrm{M}$. Substitution of another hydroxyl or carboxylic acid/ester group at the phenyl ring further increased the potency of TS inhibition and cell growth inhibition. Most effective were compounds If and Ic in which extra carboxylic acid/ester was present at the phenyl ring with nanomolar $\mathrm{IC}_{s i}$ values of 0.0044 and $0.0093 \mu \mathrm{M}$ against human $\mathrm{TS}$ and submicromolar cytotoxic growth inlibition against all four tumor cell lines.
\end{abstract}

Key Words : Quinazolinone. Nonclassical antifolates, Thymidylate sy nthase inlubitors. In vitro antitumor activity

\section{Introduction}

$N^{5} N^{10}$-Methylenetetrahydrofolate (1) is a cofactor for the catalytic action of thymidylate synthase (TS: EC 2.1.1.45). the enzyme involved in the sole de nowo biosynthesis of deoxythymidine-5'-monophosphate (dTMP. thymidylate. 2) from deoxyuridine-5'-monophosphate (dUMP. 3). In the process of this catalytic action. TS forms a temary complex with $N^{5} N^{10}$-methylenetetrahydrofolate and dUMP. and this complex is cleaved into dihydrofolate (4) and dTMP with simultaneous methylene transfer and hydride reduction. resulting in the methylation of dUMP to dTMP (Figure 1). ${ }^{l}$

Since DNA contains thymine as a base component. rapidly dividing cells such as cancer cells where proliferation is very rapid require an abundant supply of dTMP for DNA synthesis and repair. ${ }^{2-4}$ The maximal activity of cellular TS for dTMP synthesis occurs during the $S$ phase of the cell cycle and is 20 -fold higher in rapidly dividing cells than in nondividing cells. ${ }^{5}$ Thus, the inhibition of dTMP synthesis leads to a "thymineless cell death" particularly in cancer

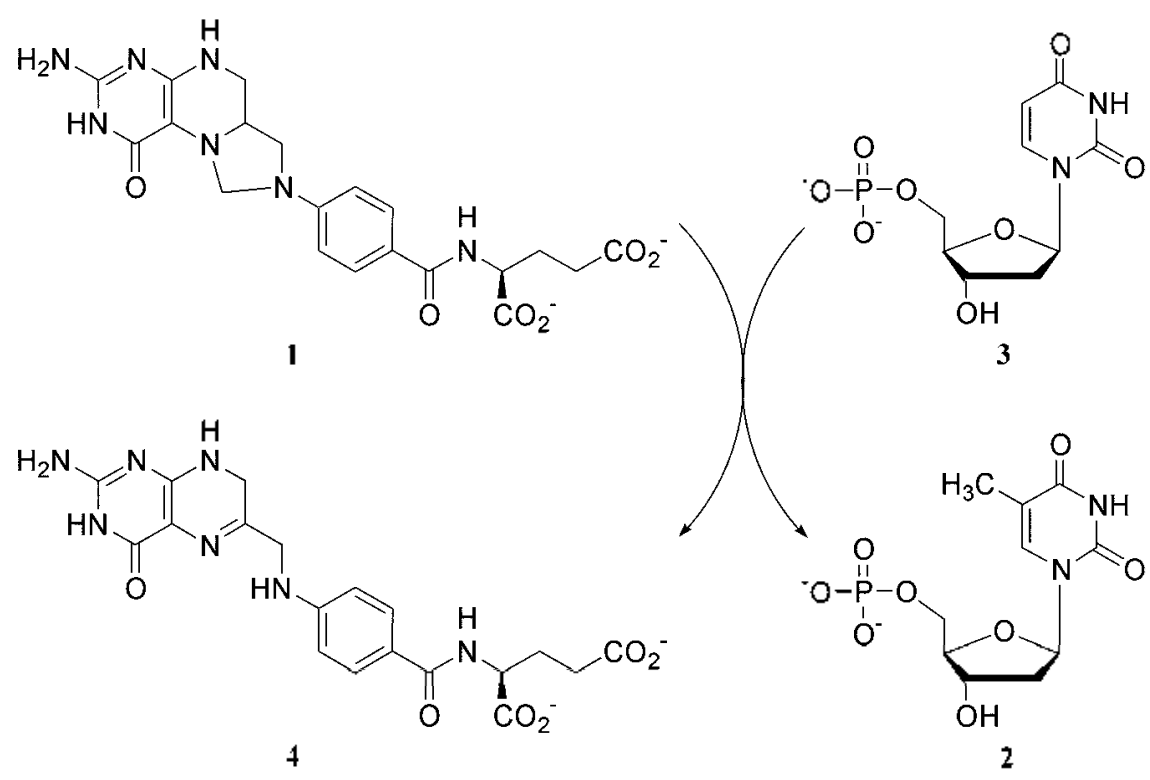

Figure 1

\footnotetext{
"To whom correspondence should be addressed. Tel: -82-2-2287-5143; Fax: +82-2-396-6133; e-mail: djbaek: $\bar{c}$ 'smu.ac.kr
} 
<smiles>C#CCN(Cc1ccc2nc(N)[nH]c(=O)c2c1)c1ccc(C(=O)N[C@@H](CCC(=O)O)C(=O)O)cc1</smiles><smiles>Cc1nc2ccc(CN(C)c3ccc(C(=O)N[C@@H](CCC(=O)O)C(=O)O)s3)cc2c(=O)[nH]1</smiles>

6<smiles>Cc1ccc2nc(N)[nH]c(=O)c2c1Sc1ccncc1</smiles>

7

Chart 1

cells. and as a result. inhibition of TS has proven to be an attractive target for anticancer chemotherapy for many years. ${ }^{6}$

One of the first examples of selective. tight-binding inhibitors of TS as classical antifolates is $N^{\mathrm{l}}$-propargy $\mathrm{l}-5.8$ dideazafolic acid (CB3717. 5) reported by Jones et af. in 1981 (Chart 1) ${ }^{7}$ The antitumor activity was actually observed in phase 1 and 2 clinical trials with cancer patients. ${ }^{8}$ Unfortunately. however dose-related nephrotoxicity and dose-unrelated hepatotoxicity and malaise limited the clinical utility of $5{ }^{9} \mathrm{~N}-[[5$-[[(1.4-Dihydro-2-methy'-4-oxo6-quinazolinyl)methyl]methylamino]-2-thienyl] carbony'l]L-glutamic acid (ZD1694. raltitrexed. Tomudex $x^{(5)}$. 6) has been developed later as a non-nephrotoxic and highly active analog of 5. and is currently used for cancer treatment clinically. ${ }^{10}$

The potent cytotoxic activity of these classical antifolates is dependent upon the glutamate component. which is essential for the active uptake into cells via the reduced folate carrier and for the binding of antifolate to the active site of TS through hydrogen bonding of $\alpha$ - and $\gamma$ carboxylates of glutamate component to the basic amino acid residues of the enzyme. ${ }^{1]}$ This component is further polyglutamated by folylpolyglutamate synthetase (FPGS) to produce noneffluxing poly- $\gamma$ glutamates for the retentive property inside cells for the higher binding affinity and cytotoxic activity. ${ }^{11.12}$ The very presence of this glutamate component is however. detrimental to the activity of these compounds as antitumor agents: Defective cell transport by mutation of the cancer cells themselves induces dnig resistance. and unnecessarily long retention inside normal cells results in toxicity to the host.

These complications may be overcome by deletion or modification of the glutamate moiety from the folate analogs. converting these analogs into nonclassical lipophilic inhibitors of TS. Recently. 2-amino-6-methy l-5-(pyridin-4ylsulfanyl)-3H-quinazolin-4-one (AG-337, Thymitaq ${ }^{\mathbb{2}}$, 7) which does not bear the appended glutamic acid has been reported as a nonclassical inhibitor of human and $E$. coll TS with the inhibitory binding constants $\left(K_{\mathrm{i}}\right)$ of 15 and $49 \mathrm{nM}$. respectively. ${ }^{13}$ This compound further showed high cytotoxic activity against tumor cells in culture. ${ }^{1+}$ and the clinical trials resulted in regression in tumor size in some treated cancer patients. ${ }^{15}$

Meantime, we wondered whether potent inhibition of TS could be achieved with nonclassical quinazolinone derivatives in which the glutamic acid moiety of the classical antifolates is substituted by a group containing aromatic ring and carboxylic acid/ester. Our strategy was to leave one carbosylic acid/ester group at the $\alpha$ - or $\gamma$ position of the glutanic acid with the hope that hydrogen bonding of the carbosylic acid/ester at the active site would be retained for the binding affinity while its lipophilicity attributed by the presence of the aromatic ring would be increased for the passive transport through cell membrane. Thus. this modification of glutamic acid would make it possible to take advantages of both classical and nonclassical antifolates. Toward that purpose. we designed three series of nonclassical quinazolinone analogs as TS inhibitors: Compounds I. II. and III containing phenylglycine phenylalanine and aminobenzoic acid moiety respectively (Chart 2). Herein.<smiles>[R]C(=O)[C@@H](NC(=O)c1ccc(Sc2c(C)ccc3nc(N)[nH]c(=O)c23)cc1)c1cccc([X])c1</smiles><smiles>[X]c1ccc(C[C@@H](NC(=O)c2ccc(Sc3c(C)ccc4nc(N)[nH]c(=O)c34)cc2)C(=O)O)cc1</smiles><smiles>[R]OC(=O)c1cccc(NC(=O)c2ccc(Sc3c(C)ccc4nc(N)[nH]c(=O)c34)cc2)c1</smiles>

Chart 2 
we report on the synthesis of these lipophilic quinazolinone compounds and evaluation for the inhibition against TS and for the cytotoxic growth inhibition of several tumor cell lines of murine and human origin in vitro.

\section{Synthesis}

The target compounds Ia-f were synthesized according to Scheme 1. First. quinazolinylsulfanyl benzoic acid $8^{13}$ was reacted with the appropriately substituted phenylglycine methyl esters 9 in the presence of diphenylphosphoryl azide (DPPA) to form amide esters Ia-c. and then each of these esters was hydrolyzed to generate carboxylic acids Id-f.

The (S)-phenylglycine methyl esters $9 \mathrm{~b}$ and $9 \mathrm{c}$ were not commercially available. thus made from the appropriate benzaldehydes by diastereoselective Strecker synthesis using 2-phenylglycinol as a chiral auxiliary ${ }^{16}$ as shown in Scheme 2: Benzaldehyde $\mathbf{1 0}$ was reacted with $(R)$-2-phenylglycinol to form imine intermediate. which was reacted in situ with trimethylsilyl cyanide (TMSCN) to lead to the stereospecific addition of cyanide to the imine. (S)- $\alpha$-Amino nitrile 11 thus obtained as a major isomer was then treated with saturated methanolic $\mathrm{HCl}$ for $5 \mathrm{hr}$ at room temperature to convert the cyano group into methyl ester 12 and subsequently treated with lead tetraacetate and dilute $\mathrm{HCl}$ to remove the $(R)$-2phenylglycinol chiral auxiliary. affording the desired methyl ester 9.

Compounds Ig-i were also prepared similarly by the reaction of 8 with the corresponding amines. $(R)$-phenylglycine methyl ester. $(R)$ - $\alpha$-methylbenzy lamine, and $(S)$-2phenylglycinol, respectively. Compound $\mathbf{I j}$. thiophene analog of Ia. was synthesized according to Scheme 3. First. thiol 13 was protected as thiocarbonate. and the 5-position of the thiophene ring was carboxylated by lithiation followed

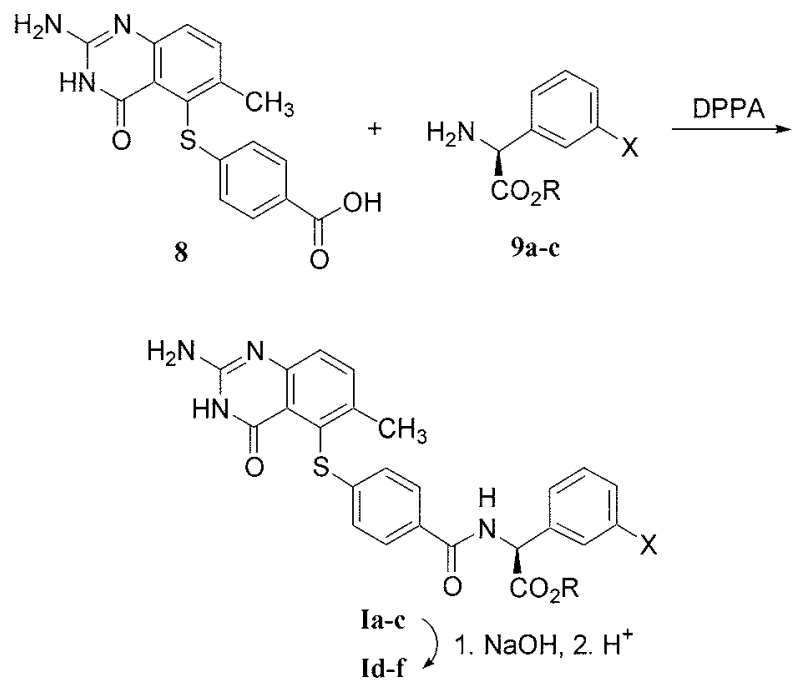

a, $\mathrm{R}=\mathrm{CH}_{3}, \mathrm{X}=\mathrm{H} ; \quad \mathrm{b}, \mathrm{R}=\mathrm{CH}_{3}, \mathrm{X}=\mathrm{OH} ; \quad$ c, $\mathrm{R}=\mathrm{CH}_{3}, \mathrm{X}=\mathrm{CO}_{2} \mathrm{CH}_{3}$ d, $\mathrm{R}=\mathrm{H}, \mathrm{X}=\mathrm{H} ; \quad \mathrm{e}, \mathrm{R}=\mathrm{H}, \mathrm{X}=\mathrm{OH} ; \quad$ f, $\mathrm{R}=\mathrm{H}, \mathrm{X}=\mathrm{CO}_{2} \mathrm{H}$

Scheme 1

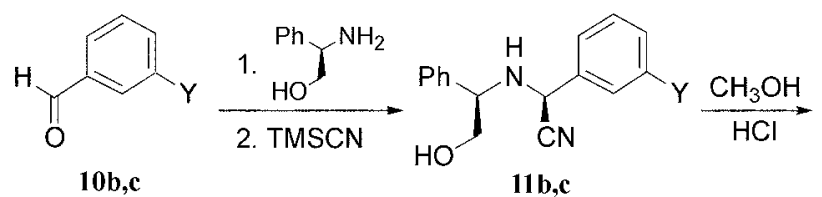

$\mathbf{b}, \mathrm{Y}=\mathrm{OH} ; \mathbf{c}, \mathrm{Y}=\mathrm{CN}$<smiles>[X]c1cccc(C(NC(CO)c2ccccc2)C(=O)OCC(C)(C)C(C)(C)C)c1</smiles>

b, $\mathrm{X}=\mathrm{OH} ; \mathbf{c}, \mathrm{X}=\mathrm{CO}_{2} \mathrm{CH}_{3}$

Scheme 2<smiles>CCOC(=O)c1ccc(S(=O)(=O)CN(C(=O)Cl)c2ccccc2)s1</smiles><smiles>CCOC(=O)c1ccc(S)s1</smiles>

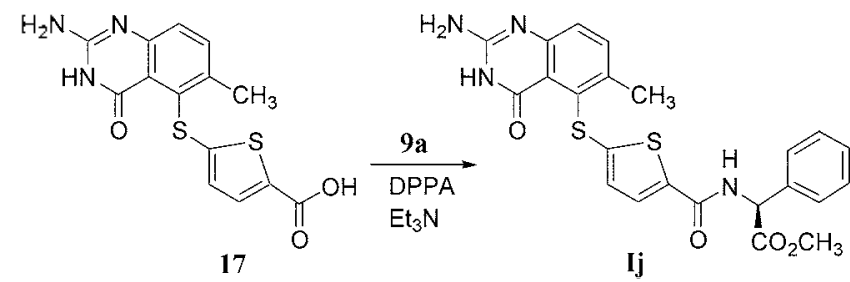

Scheme 3

by the reaction with ethyl cluoroformate to produce 14 . Then the thiocarbonate group was deprotected to regenerate thiol 15. which was coupled with bromoquinazolinone $\mathbf{1 6}$. followed by hydrolysis of the ester group to give thienyl acid 17. a thiophene analog of 8 . This acid 17 was reacted with $9 \mathbf{a}$ as in Scheme 1, resulting in the formation of $\mathbf{I j}$

The other series of compounds II and III were also synthesized analogously from the reaction of $\mathbf{8}$ with the corresponding phenylalanine methyl esters and aminobenzoic acid methỵl esters. respectively.

\section{Biological Activity}

The biological activities of the test compounds I. II. and III were evaluated for the inlubition against bacterial ( $L$. casei) TS and/or human TS and for the cell growth inhibition of tumor cell lines of murine and luman origin in vitro. The TS inhibition constants $\mathrm{IC}_{\text {sij }}$ were deternined by 
steady'-state analysis against the cofactor $N N^{11}$-methy lenetetrahydrofolate 1 under conditions of saturating dUMP. Enzy'me activity in the $L$ casei TS inhibition assay was measured by following the change in UV absorbance at 340 num. ${ }^{17}$ and enzyme activity in the human TS inhibition assay was measured by the tritium release method. ${ }^{18}$ Cell growth inhibition constants $\mathrm{IC}_{\text {si }}$ were determined by MTT $^{19}$ colorimetric assay ${ }^{20}$ against four different tumor cell lines: L1210 (mouse lymphocytic leukemia). LY3.7.2C TK-/- (mouse lymphoma. thymidine kinase deficient). CCRF-CEM (human leukemia). and HT-29 (human colon adenocarcinoma). Cell growth was measured spectrophotometrically following a 3or 4-day incubation in RPMI-1640 medium containing 5\% fetal calf serum and a 4-hr treatment with MTT.

\section{Results and Discussion}

The results of the biological activities are summarized in Table 1. Most of the target compounds were generally potent inhibitors of $L$. casei and human TS. with $\mathrm{IC}_{50}$ values within the narrow range of 0.2-10 $\mu \mathrm{M}$ and $0.003-0.03 \mu \mathrm{M}$. respectively. The above data of $L$. casei TS inhibition are comparable to $1.1 \mu \mathrm{M}$. that of the reference compound 7 .

In this series of compounds. carboxylic acid analogs were 1.7- to 21-times more potent than the corresponding esters as proved by the comparison of each of the following pairs: $\mathbf{I}$ / Id Ib/Ie and Ic/If. This result suggests that free $\alpha$-carboxyl acid contributes to the enhanced potency by the increased binding of the quinazolinone derivatives to TS via hydrogen bonding of the carboxylic acid to the basic amino acid residues in the active site of TS. This finding was further supported by the observation that the hydroxymethyl analog Ii. in which $\mathrm{OH}$ group could be involved in the hydrogen bonding. showed an $\mathrm{IC}_{s(\mathrm{i}}$ value of $1.1 \mu \mathrm{M}$ against $L$. casei TS. which was comparable to those of the carboxylic acid analogs Id. Ie and If: while the corresponding methyl analog Ih. the compound that hydrogen bonding is not possible. had an $\mathrm{IC}_{5 \mathrm{ic}}$ value of $10 \mu \mathrm{M}$. 9-fold less potent than Ii. Most effective against human TS were compounds Ie. If. and IIb in which hydroxyl or carboxylic acid group was present at the phenyl ring as an additional hy'drogen donor. with nanomolar IC 5 ic values of $0.0031-0.0063 \mu \mathrm{M}$.

Most of the target compounds were also cytotoxic against tumor cell lines with $\mathrm{IC}_{\text {Sij }}$ values of as low as $0.050 \mu \mathrm{M}$. Contrary to the TS inhibition. however. esters were generally more active than their corresponding carboxylic acids as shown by the comparison of each of the Ia/Id. IIa/ IIf. and IIIa/IIIb pairs in particular. and this inversion of potency between carboxylic acids and esters is due to the likelihood that the more lipophilic esters have greater permeability through the lipophilic cell membrane than the less lipophilic acids. Similar effect was also shown in the comparison between Ih and Ii: The more lipophilic methyl analog Ih showed higher cytotoxicity than the less lipophilic hydroxymethyl analog Ii in L1210. LY TK-/- and HT-29. Among the target compounds. Ia. Ic. If. IIa. IIb. and IIIa exhibited submicromolar cell growth inhibition. and most effective is compound If. which is 2- to 16-times more potent than the reference compound 7 for the cell lines studied in this research.

When the enantiomeric pair Ia and Ig was compared each other in order to investigate the enantioselectivity in the potency of the inhibition studies. Ia was 1.4- to 1.8-times more potent in the TS inhibition and 1.7- to 4.1-times more cytotoxic in the cell growth inhibition than Ig. It indicates that $(S)$ enantiomer is more potent than the corresponding $(R)$ enantiomer against both TS inhibition and cell growth inhibition. even though the enantioselectivity is not very high.

Thiophene analog $\mathbf{I j}$ did not increase the potency of both the TS inhibition and cell growth inhibition of the phenyl analog Ia.

These results prove that potent inhibition of TS and tumor cell growth can be achieved with nonclassical quinazolinone derivatives containing more lipophilic phenylglycine. phenylalanine. or aminobenzoic acid component. and it is thought that these lipophilic moieties of the target compounds may be quite tolerable in the binding region of the TS active site where glutamate moiety is originally bound in the normal physiological or pathological procedure. and lipophilicity of these moieties may be rather beneficial for the passive transport of these compounds across cell membrane. Substitution of another hydroxyl. carboxylic acid. or ester group at the phenyl ring further increased the potency of TS inhibition and cytotoxic cell growth inhibition. We are presently expanding the scope of this finding in order to discover more potent nonclassical inhibitors of TS.

\section{Experimental Section}

Melting points were determined on a Thomas-Hoover Unimelt apparatus and are uncorrected. Mass spectra were determined on an Extrel ELQ-400 mass spectrometer using electospray ionization with amımonia as a carrier gas. ${ }^{1} \mathrm{H}$ NMR spectra were determined at $300 \mathrm{MHz}$ on a Bruker AMX-R300 spectrometer in DMSO-d $\mathrm{d}_{6}$ or $\mathrm{CDCl}_{3}$. and chenical shifts are reported in $\delta$ scale in parts per million from tetramethylsilane as an internal standard. Peak multiplicities are designated as follows: s. singlet: d. doublet: dd. doublet of doublets: t. triplet: q. quartet: m. multiplet: and bs. broad singlet. IR absorption spectra were taken on a PerkinElmer FTIR 1750 spectrometer from $\mathrm{KBr}$ pellets. Elemental microanalysis was performed on a CE Instrument EA1110 and gave results for the elements stated with $\pm 0.4 \%$ of the theoretical values. Thin-layer chromatography (TLC) was performed with E. Merck silica gel $60 \mathrm{~F}-254$ precoated glass plates $(0.25 \mathrm{~mm})$. Flash colunu chromatography was performed using E. Merck silica gel $60\left(40-63^{\prime} \mu \mathrm{m}\right){ }^{21}$ Tetrahydrofuran (THF) and dioxane were distilled from sodium benzophenone ketyl under nitrogen. and $N_{1} N$ dimethylformamide (DMF) and methylene chloride were distilled from magnesium sulfate and calcium hydride. respectively. Concentrations were performed on a rotary evaporator at $\leq 45^{\circ} \mathrm{C}$ (20 torr) unless otherwise noted. 
Table 1. Thymidylate Synthase and Cell Growth Inhibition of Quinazolinone Derivatives

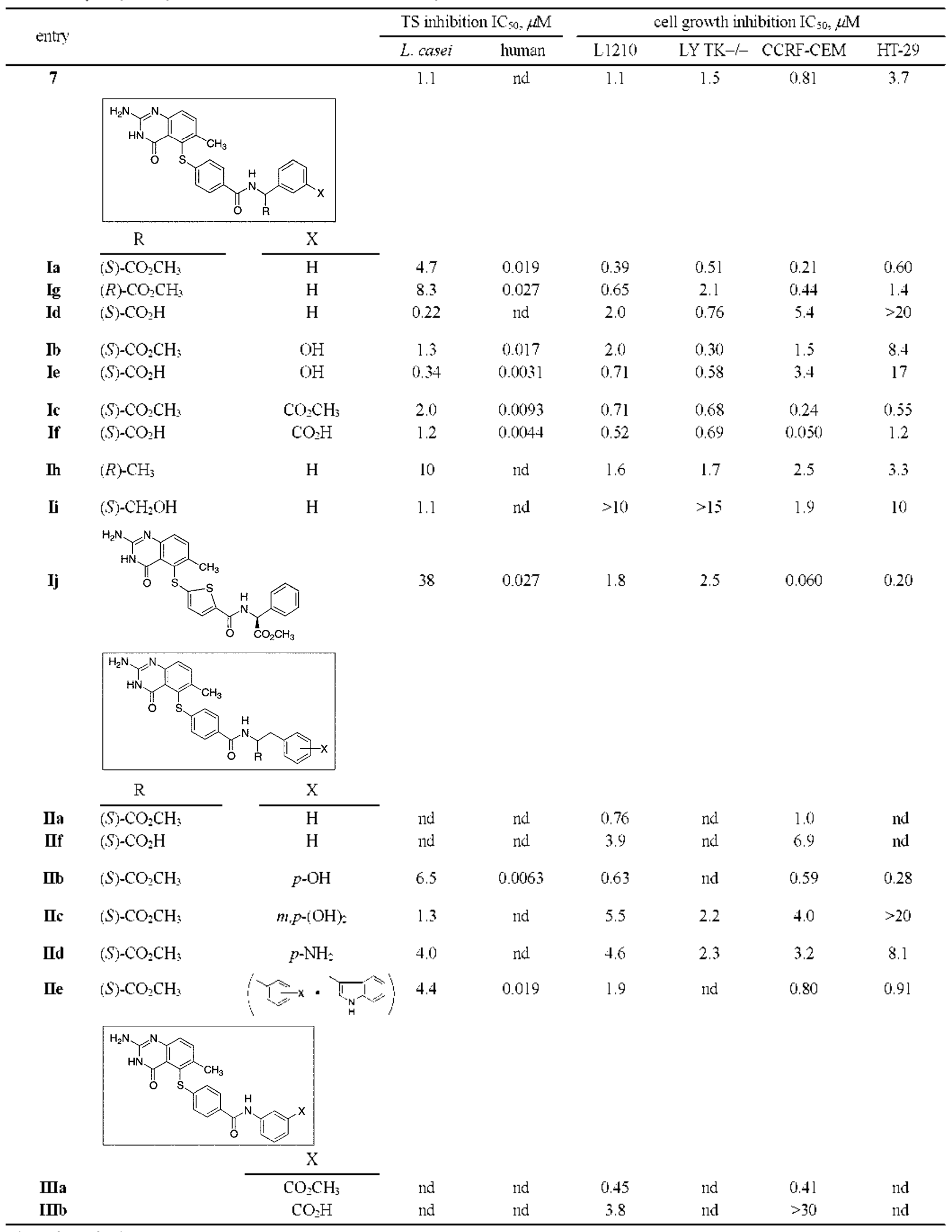


Method A: $N$-[4-[(2-Amino-6-methy]-4-oxo-3,4-dihydroquinazolin-5-yl)-sulfanyl] benzoyl]-(S)-phenylglycine methyl ester (Ia). A stirred solution of benzoic acid $8(0.20 \mathrm{~g} .0 .61$ mmol) and (S)-phenylglycine methyl ester $\mathrm{HCl}$ salt 9a $(0.135 \mathrm{~g} .0 .67 \mathrm{mmol})$ in anhydrous DMF $(15 \mathrm{~mL})$ was cooled to $0{ }^{\circ} \mathrm{C}$. To this cold solution was added diphenylphosphoryl azide $(0.14 \mathrm{~mL} .0 .67 \mathrm{~mm}$ ) $)$. After stirring for 30 min. triethylamine $(0.19 \mathrm{~mL} .1 .34 \mathrm{mmol})$ was added. and the reaction mixture was allowed to stir for $3 \mathrm{hr}$ at room temperature. The solvent was then removed under vacuum. and the residue was purified by flash chromatography' on silica using $\mathrm{CH}_{2} \mathrm{Cl} / \mathrm{MeOH}(13: 1)$ to give $\mathrm{Ia}$ as a yellow solid (0.124 g. $43 \%$ ): $\mathrm{mp} 266-267^{\circ} \mathrm{C}$ : IR ( $\left.\mathrm{KBr}\right) 3340.3180$. 1740. 1670. 1640. $1590 \mathrm{~cm}^{-1}:{ }^{1} \mathrm{H}$ NMR (DMSO-d $) \delta 2.29$ (s. $3 \mathrm{H}$ ). 3.64 (s. $3 \mathrm{H}$ ). 5.63 (t. $1 \mathrm{H}) .6 .49$ (s. $2 \mathrm{H}$ ). 6.95 (d. $2 \mathrm{H} . J$ $=8.5 \mathrm{~Hz}) .7 .26(\mathrm{~d} .1 \mathrm{H} . J=8.4 \mathrm{~Hz}) .7 .34-7.47(\mathrm{~m} .5 \mathrm{H}) .7 .57$ (d. $1 \mathrm{H} . J=8.7 \mathrm{~Hz}) .7 .73($ d. $2 \mathrm{H} . J=8.5 \mathrm{~Hz}$ ). $9.07(\mathrm{~d} .1 \mathrm{H} . J=$ $7.1 \mathrm{~Hz}$ ): Mass me $474\left(\mathrm{M}^{+}\right)$: Anal. $\left(\mathrm{C}_{3} \leq \mathrm{H}_{32} \mathrm{~N}_{4} \mathrm{O}_{4} \mathrm{~S}\right)$ C. H. N. S.

Method B: $N$-[4-[(2-Amino-6-methy]-4-oxo-3,4-dihydroquinazolin-5-yl)-sulfanyl]benzoyl]-(S)-phenylglycine (Id). To a solution of methyl ester Ia $(0.050 \mathrm{~g} .0 .105 \mathrm{mmol})$ in methanol $(5 \mathrm{~mL})$ was added an aqueous $1 \mathrm{~N} \mathrm{NaOH}$ solution $(0.5 \mathrm{~mL})$, and the reaction mixture was stirred for $3 \mathrm{hr}$ at 70 ${ }^{\circ} \mathrm{C}$. The solution was then evaporated to dryness. and the sodium salt was taken up in $\mathrm{H}_{2} \mathrm{O}(2 \mathrm{~mL})$ and acidified to $\mathrm{pH}$ 4 with an aqueous $2 \mathrm{~N} \mathrm{HCl}$ solution at $0^{\circ} \mathrm{C}$. The precipitated solid was filtered and washed with cold $\mathrm{H}_{2} \mathrm{O}(5 \mathrm{~mL})$, and dried under vacuum over $\mathrm{CaSO}_{4}$ to give Id as a yellow solid (0.041 g. 85\%): mp 228.5-230 ${ }^{\circ} \mathrm{C}$ : IR (KBr) 3400.1705 . 1595. 1475. 1380. $1290 \mathrm{~cm}^{-1}:{ }^{1} \mathrm{H}$ NMR (DMSO-d 6 ) $\delta 2.30$ (s. $3 \mathrm{H}$ ). 5.56 (d. $1 \mathrm{H} . J=7.5 \mathrm{~Hz}$ ). 6.88 (bs. $2 \mathrm{H}$ ). 6.97 (d. $2 \mathrm{H} . J$ $=8.3 \mathrm{~Hz}), 7.30-7.37(\mathrm{~m}, 5 \mathrm{H}), 7.47(\mathrm{~d}, 2 \mathrm{H}, J=6.4 \mathrm{~Hz}) .7 .61$ (d. $1 \mathrm{H} . J=8.7 \mathrm{~Hz}) .7 .74$ (d. $2 \mathrm{H} . J=8.6 \mathrm{~Hz}$ ). $8.89($ d. $1 \mathrm{H} . J=$ $7.5 \mathrm{~Hz})$. Mass me $461(\mathrm{M}+1)$

(S)-2-(3-Hydroxyphenyl)glycine methyl ester (9b). To a solution of 3-hydroxybenzaldehyde $10 \mathrm{~b}(0.465 \mathrm{~g} .3 .81$ $\mathrm{mmol}$ ) in methanol $(5 \mathrm{~mL})$ was added $(R)$-2-phenylglycinol $(0.52 \mathrm{~g} .3 .81 \mathrm{mmol})$ and stirred for $2 \mathrm{hr}$ at room temperature. The reaction mixture was then cooled to $0{ }^{\circ} \mathrm{C}$. and TMSCN $(0.81 \mathrm{~g} .8 .1 \mathrm{mmol}$ ) was added over $15 \mathrm{~min}$. After stirring for $12 \mathrm{hr}$ at room temperature. an aqueous $3 \mathrm{~N} \mathrm{HCl}(20 \mathrm{~mL})$ was added to the reaction mixture. The mixture was extracted with ethyl acetate and the organic layer was dried with anhydrous magnesium sulfate. and filtered. The solvent was then removed under vacuum. and the residue was purified by flash chromatography on silica using $\mathrm{CH}_{2} \mathrm{Cl} / 3 \mathrm{MeOH}$ (20: 1) to give a yellow liquid $11 \mathrm{~b}(0.92 \mathrm{~g} .90 \%)$.

To a solution of $11 \mathrm{~b}(0.92 \mathrm{~g} .3 .43 \mathrm{mmol})$ in methanol (30 $\mathrm{mL}$ ) was added dry ethereal $\mathrm{HCl}(15 \mathrm{~mL})$ and stirred for $5 \mathrm{hr}$ at room temperature. The reaction mixture was concentrated under vacuum. and the residue was neutralized with phosphate buffer $(\mathrm{pH} 7)$ and extracted with ethyl acetate. The solvent was evaporated under vacuum. and the residue was purified by flash chromatography on silica to give $12 \mathrm{~b}$ as colorless liquid $(0.72 \mathrm{~g} .70 \%)$.

To a solution of $12 \mathrm{~b}(0.72$ g. $2.39 \mathrm{mmol})$ in $\mathrm{CH}_{2} \mathrm{Cl}_{5} /$
$\mathrm{MeOH}(2: 1.20 \mathrm{~mL})$ was added lead tetraacetate $(1.3 \mathrm{~g}$. $2.94 \mathrm{mmol}$ ) at $0^{\circ} \mathrm{C}$ and the reaction mixture was stirred for 5 min at the same temperature. To this reaction mixture was added phosphate buffer $(\mathrm{pH} \mathrm{7)}$ and stirred for $30 \mathrm{~min}$ at room temperature. After the reaction mixture was filtered. the organic layer was separated and the aqueous layer was extracted with methylene chloride. After concentration of the combined organic layer under vacuum. the residue was dissolved in ether $(10 \mathrm{~mL})$, treated with an aqueous $2 \mathrm{~N} \mathrm{HCl}$ $(20 \mathrm{~mL}$ ), and the reaction mixture was stirred for $15 \mathrm{~min}$ at room temperature. The aqueous layer was separated and concentrated to dryness under vacuum. The residue was then neutralized with phosphate buffer $(\mathrm{pH} \mathrm{7)}$, and the mixture was extracted with ethyl acetate. The solvent was evaporated under vacuum, and the residue was purified by flash chromatography on silica using $\mathrm{CH}_{2} \mathrm{Cl}_{4} \mathrm{MeOH}(9: 1)$ to give $9 \mathrm{~b}$ as a white solid $(0.30 \mathrm{~g} .69 \%): \mathrm{mp} 175-176^{\circ} \mathrm{C}$ dec: IR (KBr) 3330, 3270, 3230,1740, $1595,1480 \mathrm{~cm}^{-1}:{ }^{1} \mathrm{H}$ NMR (DMSO-d $\left.\mathrm{d}_{6}\right) \delta 2.16$ (bs. 2H). 3.59 (s. 3H). 4.42 (s. lH). 6.66 (d. $1 \mathrm{H} . J=8.0 \mathrm{~Hz}$ ). 6.78 (s. $2 \mathrm{H}$ ). 7.11 (dd. $1 \mathrm{H} . J=7.9$. $8.0 \mathrm{~Hz}$ ). 9.39 (bs. $1 \mathrm{H})$ : Mass me $182(\mathrm{M}+1)$.

N-[4-[(2-Amino-6-methy]-4-0xo-3,4-dihydroquinazolin5-yl)-sulfanyl]benzoyll-(S)-2-(3-hydroxyphenyl)glycine methyl ester (Ib). The coupling reaction of benzoic acid 8 $(0.060 \mathrm{~g} .0 .183 \mathrm{mmol})$ and $(S)-2$-(3-hydroxyphenyl)glycine methyl ester $9 \mathrm{~b}(0.0365$ g. $0.202 \mathrm{mmol})$ was performed as described in Method $\mathbf{A}$, and $\mathbf{I b}$ was obtained as a white solid $(0.038$ g. $42 \%)$ : $\mathrm{mp} 280^{\circ} \mathrm{C}$ dec: IR (KBr) 3400.3100 . 1740. $1680.1600 \mathrm{~cm}^{-1}$ : ${ }^{1} \mathrm{H}$ NMR (DMSO-d 6 ) $\delta 2.30$ (s. $3 \mathrm{H}$ ). 3.65 (s. $3 \mathrm{H}), 5.51$ (d. $1 \mathrm{H} . J=6.9 \mathrm{~Hz}), 6.32$ (bs. $2 \mathrm{H}), 6.74$ (d. $1 \mathrm{H} . J=8.5 \mathrm{~Hz}$ ). 6.86 (d. $2 \mathrm{H} . J=7.6 \mathrm{~Hz}$ ). 6.95 (d. $2 \mathrm{H} . J=8.4$ Hz). 7.17 (dd. $1 \mathrm{H}, J=7.6 .7 .8 \mathrm{~Hz}$ ). 7.25 (d. $1 \mathrm{H} . J=8.4 \mathrm{~Hz}$ ). 7.56 (d. $1 \mathrm{H} . J=8.5 \mathrm{~Hz}$ ). 7.74 (d. $2 \mathrm{H} . J=8.4 \mathrm{~Hz}$ ). 8.97 (d. $1 \mathrm{H} . J=6.9 \mathrm{~Hz}$ ). 9.49 (s. $1 \mathrm{H}$ ). 10.77 (bs. 1H): Mass $m e 491$ $(\mathrm{M}+1)$ : Anal. $\left(\mathrm{C}_{3} \mathrm{H}_{22} \mathrm{~N}_{4} \mathrm{O}_{5} \mathrm{~S}\right)$ C. H. N. S.

$\mathrm{N}$-[4-[(2-Amino-6-methy]-4-0xo-3,4-dihydroquinazolin5-yl)-sulfanyl]benzoyll-(S)-2-(3-hydroxyphenyl)glycine (Ie). Methyl ester Ib $(0.030 \mathrm{~g})$ was hydrolyzed as in Method B. and Ie was obtained as a pale yellow solid $(0.028 \mathrm{~g}$. 97\%): IR ( $\mathrm{KBr}) 3380.3220 .1720 .1480 .1300 \mathrm{~cm}^{-1}:{ }^{1} \mathrm{H}$ NMR (DMSO-d 6 ) $\delta 2.33$ (s. 3H). 5.45 (d. $1 \mathrm{H} . J=7.3 \mathrm{~Hz}$ ). 6.73 (dd. $1 \mathrm{H} . J=7.8 .1 .6 \mathrm{~Hz}$ ). 6.88 (d. $2 \mathrm{H} . J=6.2 \mathrm{~Hz}$ ). 7.01 (d. $2 \mathrm{H} . J=8.5 \mathrm{~Hz}) \cdot 7.16$ (t. $1 \mathrm{H} . J=9.2 \mathrm{~Hz}$ ). 7.43 (d. $1 \mathrm{H} . J=$ $8.4 \mathrm{~Hz}$ ). 7.75 (t. $3 \mathrm{H} . J=10.2 \mathrm{~Hz}$ ). 8.87 (d. $1 \mathrm{H} . J=7.4 \mathrm{~Hz}$ ). 9.48 (s. 1H): Mass me $499(\mathrm{M}+\mathrm{Na})$ : Anal. $\left(\mathrm{C}_{24} \mathrm{H}_{2 i j} \mathrm{~N}_{4} \mathrm{O}_{5} \mathrm{~S}\right.$ $\left.\mathrm{HCl} \cdot 2 \mathrm{H}_{2} \mathrm{O}\right)$ C. H. N. S.

(S)-2-(3-Carboxyphenyl)glycine dimethyl ester (9c). This compound was prepared from 3-cranobenzaldehyde $10 \mathrm{c}$ using the procedure described to prepare $9 \mathrm{~b}$. ${ }^{1} \mathrm{H}$ NMR (DMSO-d s) $\delta 2.38$ (bs. 2H). 3.61 (s. 3H). 3.87 (s. 3H). 4.67 (s. $1 \mathrm{H}$ ). 7.52 (t. $1 \mathrm{H}$ ). 7.69 (d. $1 \mathrm{H} . J=6.5 \mathrm{~Hz}$ ). 7.87 (d. $1 \mathrm{H} . J$ $=4.9 \mathrm{~Hz}) .8 .01(\mathrm{~s} .1 \mathrm{H})$.

$N$-[4-[(2-Amino-6-methy]-4-0xo-3,4-dihydroquinazolin5-yl)-sulfanyl]benzoyl]-(S)-2-(3-carboxyphenyl)glycine dimethyl ester (Ic). The coupling reaction of benzoic acid 8 $(0.20 \mathrm{~g} .0 .61 \mathrm{mmol})$ and $(5)-2-(3-c a r b o x y$ phenyl)glycine dimethyl ester $9 \mathrm{c}(0.135 \mathrm{~g} .0 .61 \mathrm{mmol})$ was performed as in 
Method A. and Ic was obtained as a yellow solid $(0.10 \mathrm{~g}$. $31 \%$ ): $\operatorname{mp} 216.5-217.5^{\circ} \mathrm{C}:{ }^{~} \mathrm{H}$ NMR (DMSO-d 6 ) $\delta 2.31$ (s. $3 \mathrm{H}$ ). 3.67 (s. $3 \mathrm{H}$ ) 3.87 (s. $3 \mathrm{H}$ ). 5.76 (m. $1 \mathrm{H}$ ). 6.34 (bs. $2 \mathrm{H}$ ). 6.98 (d. $2 \mathrm{H} . J=8.5 \mathrm{~Hz}$ ). 7.26 (d. lH. $J=6.8 \mathrm{~Hz}$ ). $7.72-7.78$ (m. $3 \mathrm{H}$ ). 7.95 (d. $1 \mathrm{H} . J=7.8 \mathrm{~Hz}$ ). 8.07 (s. $1 \mathrm{H}$ ). 9.19 (d. $1 \mathrm{H} . J$ $=7.2 \mathrm{~Hz}$ ). 10.82 (bs. $1 \mathrm{H}$ ): Mass me $533(\mathrm{M}+1)$ : Anal. $\left(\mathrm{C}_{27} \mathrm{H}_{24} \mathrm{~N}_{4} \mathrm{O}_{6} \mathrm{~S} \cdot 0.5 \mathrm{H}_{3} \mathrm{O}\right)$ C. H. N. S.

$\mathrm{N}$-[4-[(2-Amino-6-methyl-4-0xo-3,4-dihydroquinazolin5-yl)-sulfanyl]benzoyl]-(S)-2-(3-carboxyphenyl)glycine (If). Dimethyl ester Ic $(0.07 \mathrm{~g})$ was hydrolyzed as in Method B and If was obtained as a solid $(0.038 \mathrm{~g} .58 \%)$ : $\operatorname{mp} 286-287^{\circ} \mathrm{C}:$ IR $(\mathrm{KBr}) 3400,1715,1610.1490,1305$ $\mathrm{cm}^{-1}$ : ${ }^{1} \mathrm{H}$ NMR (DMSO-d 6$) \delta 2.29$ (s. $3 \mathrm{H}$ ). 5.65 (d. $1 \mathrm{H} . J=$ $7.3 \mathrm{~Hz}$ ) 6.47 (bs. $2 \mathrm{H}$ ). 6.96 (d. $2 \mathrm{H} . J=8.4 \mathrm{~Hz}$ ). 7.26 (d. $1 \mathrm{H}$. $J=8.4 \mathrm{~Hz}$ ). 7.49 (t. $1 \mathrm{H}) .7 .57$ (d. $1 \mathrm{H} . J=8.4 \mathrm{~Hz}) .7 .73(\mathrm{~d}$. $3 \mathrm{H} . J=8.4 \mathrm{~Hz}$ ). 7.89 (d. $1 \mathrm{H} . J=7.8 \mathrm{~Hz}$ ). 8.05 (s. $1 \mathrm{H}$ ). 9.01 (d. $1 \mathrm{H}, J=7.5 \mathrm{~Hz})$ : Mass $m e 504(\mathrm{M})$ ): Anal. $\left(\mathrm{C}_{23} \mathrm{H}_{30} \mathrm{~N}_{4} \mathrm{O}_{6} \mathrm{~S}\right.$ $\left.2 \mathrm{H}_{2} \mathrm{O}\right)$ C. H. N. O. S

$N$-[4-[(2-Amino-6-methyl-4-0xo-3,4-dihydroquinazolin5-yl)-sulfanyl|benzoyl]-( $R)$-phenylglycine methyl ester (Ig). The coupling reaction of benzoic acid $8(0.20 \mathrm{~g} .0 .61$ $\mathrm{mmol})$ and $(R)$-phenylglycine methyl ester $\mathrm{HCl}$ salt $(0.135$ g. $0.67 \mathrm{mmol}$ ) was performed as in Method $\mathbf{A}$ and $\mathbf{I g}$ was obtained as a yellow solid $(0.06 \mathrm{~g} .32 \%)$ : mp 243.5-244.5 ${ }^{\circ} \mathrm{C}: \mathrm{IR}(\mathrm{KBr}) 3350.3170 .1760 .1690 .1600,1480.1220$ $\mathrm{cm}^{-1}$ : ${ }^{1} \mathrm{H}$ NMR (DMSO-do) $\delta 2.22$ (s. 3H). 3.57 (s. 3H). 5.56 (d. $1 \mathrm{H}, J=7.1 \mathrm{~Hz}$ ). 6.33 (bs. $2 \mathrm{H}$ ). 6.87 (d. $2 \mathrm{H}, J=8.5 \mathrm{~Hz}$ ). 7.17 (d. $1 \mathrm{H} . J=8.4 \mathrm{~Hz}$ ) 7.29 (dd. $3 \mathrm{H} . J=5.5 .5 .4 \mathrm{~Hz}$ ). 7.39 $($ dd $2 \mathrm{H} . J=1.9 .1 .4 \mathrm{~Hz}) .7 .48(\mathrm{~d} .1 \mathrm{H} . J=8.5 \mathrm{~Hz}) .7 .66(\mathrm{~d}$. 2H. $J=8.5 \mathrm{~Hz}$ ). 8.99 (d. $1 \mathrm{H} . J=7.1 \mathrm{~Hz}$ ). 10.97 (bs. $1 \mathrm{H}$ ): Mass me $474\left(\mathrm{M}^{-}\right)$: Anal. $\left(\mathrm{C}_{3} \leq \mathrm{H}_{3} \_\mathrm{N}_{4} \mathrm{O}_{4} \mathrm{~S}\right)$ C. H. N. S

(S)-1-[4-[(2-Amino-6-methyl-4-oxo-3,4-dihydroquinazolin-5-yl)-sulfanyl]benzoylamino]-1-phenylethane (Ih). The coupling reaction of benzoic acid $8(0.20 \mathrm{~g} .0 .61 \mathrm{~mm}$ ) $)$ and $(S)$ - $(x$-methylbenzylamine $(0.081 \mathrm{~g} .0 .67 \mathrm{mmol})$ was performed as in Method $\mathbf{A}$. and Ih was obtained as a yellow solid $\left(0.16\right.$ g. $62 \%$ ): $m p$ 308-309 ${ }^{\circ} \mathrm{C}$ : IR (KBr) 3440.3360.

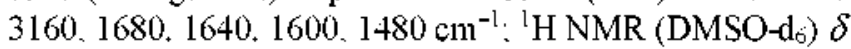
1.44 (d. $3 \mathrm{H} . J=7.1 \mathrm{~Hz}$ ). 2.28 (s. $3 \mathrm{H}$ ). 5.10 (d. $1 \mathrm{H} . J=7.5$ Hz). 6.30 (s. $2 \mathrm{H}$ ). 6.94 (d. $2 \mathrm{H} . J=8.4 \mathrm{~Hz}) .7 .10$ (d. $1 \mathrm{H} . J=$ $8.2 \mathrm{~Hz}$ ). $7.18-7.37(\mathrm{~m}, 5 \mathrm{H}) .7 .54$ (d. $1 \mathrm{H} . J=8.5 \mathrm{~Hz}) .7 .69(\mathrm{~d}$. $2 \mathrm{H} . J=8.4 \mathrm{~Hz}$ ). 8.63 (d. $1 \mathrm{H} . J=7.9 \mathrm{~Hz}):$ Mass $m e .431$ $(\mathrm{M}+1)$

(S)-2-[4-[(2-Amino-6-methyl-4-oxo-3,4-dihydroquinazolin-5-yl)-sulfanyl]benzoylamino]-2-phenylethanol (Ii). The coupling reaction of benzoic acid $\mathbf{8}(0.070 \mathrm{~g} .0 .21$ $\mathrm{mmol}$ ) and (S)-2-phenylglycinol $(0.029 \mathrm{~g} .0 .21 \mathrm{mmol})$ was performed as in Method $\mathbf{A}$. and Ii was obtained as a solid $(0.032$ g. $33 \%): m p 206-207^{\circ} \mathrm{C}: \mathrm{IR}(\mathrm{KBr}) 3280.1670 .1610$. $1480 \mathrm{~cm}^{-1}:{ }^{1} \mathrm{H}$ NMR (DMSO-d) $\delta 2.29$ (s. $3 \mathrm{H}$ ). $3.60-3.69$ (m. $2 \mathrm{H}) .4 .88(\mathrm{t} . \mathrm{lH}) .5 .04(\mathrm{~m} .1 \mathrm{H}) .6 .32$ (bs. $2 \mathrm{H}) .6 .97(\mathrm{~d}$. $1 \mathrm{H} . J=8.5 \mathrm{~Hz}) .7 .19-7.38(\mathrm{~m} .6 \mathrm{H}) .7 .56(\mathrm{~d} .1 \mathrm{H} . J=8.5 \mathrm{~Hz})$. 7.73 (d. $2 \mathrm{H} . J=8.5 \mathrm{~Hz}$ ) 8.55 (d. $1 \mathrm{H} . J=8.1 \mathrm{~Hz}$ ). 10.77 (bs. 1H): Mass me $446\left(\mathrm{M}^{-}\right)$: Anal. $\left(\mathrm{C}_{24} \mathrm{H}_{2} \mathrm{~N}_{4} \mathrm{O}_{3} \mathrm{~S} \cdot 2 \mathrm{H}_{2} \mathrm{O}\right) \mathrm{C} . \mathrm{H}$. N. O.S.

5-I(2-Amino-6-methyl-4-oxo-3,4-dihydroquinazolin-5yl)-sulfanyl]-2-thiophenecarboxylic acid (17). To a THF solution $(50 \mathrm{~mL})$ of 2-mercaptothiophene $(1.0 \mathrm{~g} .8 .61 \mathrm{mmol})$ was added triethylamine $(1.2 \mathrm{~mL} .8 .61 \mathrm{mmol})$ at $0^{\circ} \mathrm{C}$ and stirred for $10 \mathrm{~min}$ at the same temperature. To this reaction mixture was added benzyloxycarbonyl chloride $(1.23 \mathrm{~mL}$. $8.61 \mathrm{mmol}$ ) and stirred for 4 lur at room temperature. After concentration of the reaction mixture to dryness under vacuum. the residue was dissolved in ethyl acetate $(50 \mathrm{~mL}$ ) and washed with an aqueous $1 \mathrm{~N} \mathrm{HCl}$ solution $(30 \mathrm{~mL})$ and water $(30 \mathrm{~mL})$ successively. The organic layer was dried with anhydrous sodium sulfate and the solvent was evaporated under vacuum to give a yellow liquid $(2.03 \mathrm{~g}$. $8.11 \mathrm{mmol}$. 94\%). This liquid product was dissolved in anhydrous THF $(100 \mathrm{~mL})$, and a $2 \mathrm{M}$ solution of lithium diisopropylamide in hexane ( $4.4 \mathrm{~mL} .8 .8 \mathrm{mmol}$ ) was added dropwise at $-78^{\circ} \mathrm{C}$ under argon atmosphere. After $30 \mathrm{~min}$ at the same temperature. ethyl chloroformate $(0.84 \mathrm{~mL} .8 .8$ nmol) was added dropwise over $30 \mathrm{~min}$ and stirred for additional $2 \mathrm{hr}$ at room temperature. To this reaction mixture was added an aqueous $1 \mathrm{~N} \mathrm{HCl}(100 \mathrm{~mL})$. and extracted with ethyl acetate. The organic layer was evaporated under vacuum. and the residue was purified by flash chromatography on silica to give 14 as a yellow liquid ( $1.10 \mathrm{~g} .42 \%)$.

To a solution of $14(1.10 \mathrm{~g} .3 .41 \mathrm{mmol})$ in anhydrous methanol $(50 \mathrm{~mL})$ was added $28 \%$ sodium methoxide solution in methanol $(6.8 \mathrm{~mL}, 34.3 \mathrm{~mm}$ ol) and the reaction mixture was stirred for $5 \mathrm{~min}$. This reaction mixture was acidified with an aqueous $1 \mathrm{~N} \mathrm{HCl}$, and concentrated under vacuum to remove ethanol. To this residue was added water $(50 \mathrm{~mL})$ and extracted 3 times with ethyl acetate. After the organic layer was dried with anhydrous sodium sulfate. the solvent was evaporated under vacuum, and the residue was purified by flash chromatography on silica to give 5mercapto-2-thiophenecarboxylic acid ethyl ester $\mathbf{1 5}$ as a liquid $\left(0.42 \mathrm{~g} .65 \%\right.$ ): ${ }^{1} \mathrm{H}$ NMR $\left(\mathrm{CDCl}_{2}\right) \delta$ i.38 (t. $3 \mathrm{H} . J=7.1$ Hz). 4.33 (q. $3 \mathrm{H}) .7 .13$ (d. $1 \mathrm{H} . J=4.0 \mathrm{~Hz}$ ). 7.66 (d. $1 \mathrm{H} . J=$ $3.9 \mathrm{~Hz}$ ).

To a suspension of sodium hydride $(0.053 \mathrm{~g} .2 .20 \mathrm{mmol})$ in anhydrous N.N-dimethylacetamide $(10 \mathrm{~mL})$ at $0{ }^{\circ} \mathrm{C}$ was added thiol $15(0.414$ g. $2.20 \mathrm{mmol})$, and the heterogeneous mixture was stirred for $30 \mathrm{~min}$ at room temperature. To the reaction mixture was added 2-amino-5-bromo-6-methyl-3 $\mathrm{H}$ quinazolin-4-one ${ }^{13} 16$ (0.238 g. $\left.0.79 \mathrm{mmol}\right)$, copper(I) bromide $(0.057 \mathrm{~g} .0 .40 \mathrm{mmol})$, and copper(I) oxide $(0.057 \mathrm{~g}$. $0.40 \mathrm{mmol}$ ), and the mixture was heated at $90^{\circ} \mathrm{C}$ for $4 \mathrm{hr}$. The solvent was evaporated to dryness. $\mathrm{H}_{2} \mathrm{~S} /$ methanol solution $(20 \mathrm{~mL})$ was added to the residue. and the mixture was stirred for $1 \mathrm{hr}$. The mixture was filtered. and the filtrate was evaporated to dryness. The residue was purified by flash chromatograply on silica using $\mathrm{CH}_{2} \mathrm{Cl}_{1} / \mathrm{MeOH}(13: 1)$ to give a coupling product as a yellow solid $(0.163 \mathrm{~g} .57 \%)$ : $\mathrm{mp}$ $224-225^{\circ} \mathrm{C}:{ }^{1} \mathrm{H}$ NMR (DMSO-d 6 ) $\delta 1.23$ (t. $3 \mathrm{H}$ ). 2.40 (s. $3 \mathrm{H}$ ). 4.20 (q. $2 \mathrm{H}$ ). 6.44 (s. $2 \mathrm{H}$ ). 7.00 (d. $1 \mathrm{H} . J=4.0 \mathrm{~Hz}$ ). 7.26 (d. $1 \mathrm{H}, J=8.5 \mathrm{~Hz}$ ). 7.54 (d. $1 \mathrm{H}, J=8.5 \mathrm{~Hz}) .7 .60$ (d. $1 \mathrm{H} . J=$ $3.8 \mathrm{~Hz}$ ) 10.97 (s. $1 \mathrm{H}$ ).

This ethyl ester $(0.16 \mathrm{~g} .0 .44 \mathrm{mmol})$ was hydrolyzed with an aqueous $3 \mathrm{~N} \mathrm{NaOH}$ solution $(10 \mathrm{~mL})$ at $60^{\circ} \mathrm{C}$ for $3 \mathrm{hr}$. After cooling to $0^{\circ} \mathrm{C}$. this mixture was acidified to $\mathrm{pH} 2$ by 
slow addition of concentrated $\mathrm{HCl}$ and the precipitate was filtered. washed and dried to give 17 as a yellow solid (0.143 g. 97\%): $m p 246-247^{\circ} \mathrm{C}$ : IR (KBr) $3400,3200,2980,1700$. 1620.1480 $\mathrm{cm}^{-1}$. ' H NMR (DMSO-d6) $\delta 2.45$ (s. $3 \mathrm{H}$ ) 7.05 (d. $1 \mathrm{H} . J=3.9 \mathrm{~Hz}) .7 .51$ (d. $1 \mathrm{H} . J=8.5 \mathrm{~Hz}) .7 .54(\mathrm{~d} .1 \mathrm{H} . J=$ $3.9 \mathrm{~Hz}$ ) 7.77 (d. $1 \mathrm{H} . J=8.5 \mathrm{~Hz}$ ). 8.29 (s. $2 \mathrm{H}$ ). 12.94 (bs. $2 \mathrm{H})$ : Mass me $334(\mathrm{M}+1)$ : Anal. $\left(\mathrm{C}_{14} \mathrm{H}_{11} \mathrm{~N}_{3} \mathrm{O}_{3} \mathrm{~S}_{2} \cdot 0.4 \mathrm{H}_{2} \mathrm{O}\right) \mathrm{C}$. H. N. S

$N$-[5-[(2-Amino-6-methyl-4-0xo-3,4-dihydroquinazolin5-yl)-sulfanyl]-2-thenoyl]-(S)-phenylglycine methyl ester (Ij). The coupling reaction of thiophenecarboxylic acid 17 $(0.20 \mathrm{~g} .0 .60 \mathrm{mmol})$ and $(S)$-pheny lglycine methyl ester $\mathrm{HCl}$ salt $9 \mathrm{a}(0.133 \mathrm{~g} .0 .66 \mathrm{mmol})$ was performed as described in Method A. and Ij was obtained as a yellow solid $(0.064 \mathrm{~g}$. $22 \%$ ): mp 181-182 ${ }^{\circ} \mathrm{C}$ : IR (KBr) 3400, 3200. 1700, 1620. $1530.1480 \mathrm{~cm}^{-1}$. ' H NMR (DMSO-d $) \delta 2.37$ (s. $3 \mathrm{H}$ ) 3.63 (s. $3 \mathrm{H}), 5.55$ (d. $1 \mathrm{H} . J=7.0 \mathrm{~Hz}), 6.37$ (s. $2 \mathrm{H}) .6 .95$ (d. $1 \mathrm{H} . J$ $=4.0 \mathrm{~Hz}) .7 .21(\mathrm{~d}, 1 \mathrm{H}, J=8.4 \mathrm{~Hz}) .7 .39(\mathrm{~m}, 5 \mathrm{H}) .7 .50(\mathrm{~d}$. $1 \mathrm{H} . J=8.5 \mathrm{~Hz}) .7 .78(\mathrm{~d} .1 \mathrm{H} . J=4.0 \mathrm{~Hz}) .9 .09(\mathrm{~d} .1 \mathrm{H} . J=7.1$ $\mathrm{Hz}) .10 .89$ (s. $1 \mathrm{H})$; Mass $m e+41(\mathrm{M}+1)$ : Anal. $\left(\mathrm{C}_{23} \mathrm{H}_{3 j} \mathrm{~N}_{4} \mathrm{O}_{4} \mathrm{~S}_{2}\right.$ $\left.0.6 \mathrm{H}_{2} \mathrm{O}\right) \mathrm{C} . \mathrm{H}, \mathrm{N}, \mathrm{S}$.

$N$-[4-[(2-Amino-6-methyl-4-0xo-3,4-dihydroquinazolin5-yl)-sulfanyl]benzoyl]-(S)-phenylalanine methyl ester (IIa). The coupling reaction of benzoic acid $8(0.20 \mathrm{~g} .0 .61$ mmol) and (S)-pheny lalanine methyl ester $\mathrm{HCl}$ salt $(0.145 \mathrm{~g}$. $0.67 \mathrm{mmol}$ ) was performed as in Method A. and IIa was obtained as a solid $(0.135 \mathrm{~g} .45 \%)$ : $m p$ 210-212 ${ }^{\circ} \mathrm{C}$ : IR (KBr) 3420, 1660, 1600, 1560, $1480 \mathrm{~cm}^{-1}:{ }^{1} \mathrm{H}$ NMR (DMSO-d $) \delta 2.24$ (s. $3 \mathrm{H}$ ). 3.10 (m. 2H). 3.62 (s. $3 \mathrm{H}) .4 .60$ (m. 1H). 6.71 (s. 2H) .6 .94 (d. $2 \mathrm{H} . J=8.4 \mathrm{~Hz}) .7 .19$ (d. $1 \mathrm{H} . J$ $=8.4 \mathrm{~Hz}) .7 .26(\mathrm{~m} .5 \mathrm{H}) .7 .47(\mathrm{~d} .1 \mathrm{H} . J=8.5 \mathrm{~Hz}) .7 .60(\mathrm{~d}$. $2 \mathrm{H}, J=8.3 \mathrm{~Hz}), 8.73(\mathrm{~d} .1 \mathrm{H} . J=7.7 \mathrm{~Hz})$ : Mass $m e .489$ $(\mathrm{M}+1)$

N-[4-[(2-Amino-6-methyl-4-oxo-3,4-dihydroquinazolin5-yl)-sulfanyl]benzoyl]-(S)-phenylalanine (IIf). Methyl ester IIa $(0.15 \mathrm{~g})$ was hydrolyzed as in Method B and IIf was obtained as an off-white solid (0.147 g. 94\%): mp 218$220^{\circ} \mathrm{C}:$ IR (KBr) $3400,1720.1650,1600.1480 \mathrm{~cm}^{-1}:{ }^{1} \mathrm{H}$ NMR (DMSO-d $) \delta 2.38$ (s. 3H). 3.05-3.29 (m. 2H). 4.62 (m. 1H). 7.07 (d. $2 \mathrm{H} . J=8.4 \mathrm{~Hz}) .7 .27-7.37(\mathrm{~m} .5 \mathrm{H}) .7 .52$ (d. $1 \mathrm{H} . J=8.4 \mathrm{~Hz}) .7 .69$ (d. 2H. $J=8.4 \mathrm{~Hz}) .7 .87$ (d. $1 \mathrm{H} . J=8.6$ Hz). 7.92 (bs. 2H) 8.73 (d. 1 H. $J=8.1 \mathrm{~Hz}$ ) 12.74 (bs. $1 \mathrm{H}$ ): Mass $m e+75(\mathrm{M}+1)$ : Anal. $\left(\mathrm{C}_{25} \mathrm{H}_{2} \mathrm{~N}_{4} \mathrm{O}_{4} \mathrm{~S} 2 \mathrm{H}_{2} \mathrm{O}\right) \mathrm{C}$. H. N. $\mathrm{S}$.

N-[4-[(2-Amino-6-methyl-4-0xo-3,4-dihydroquinazolin5-yl)-sulfanyl]benzoyl]-(S)-tyrosine methyl ester (IIb). The coupling reaction of benzoic acid $8(0.20 \mathrm{~g} .0 .61 \mathrm{mmol})$ and $(S)$-tyrosine methyl ester $(0.131 \mathrm{~g} .0 .67 \mathrm{mmol})$ was performed as in Method A. and IIb was obtained as a yellow solid $\left(0.075\right.$ g. $24 \%$ ): mp $236-238^{\circ} \mathrm{C}$ : IR (KBr) $3400,1750.1660 .1600,1530 \mathrm{~cm}^{-1}$. ' H NMR (DMSO-d 6$)$ 2.29 (s. 3H) 2.97 (m, 2H) 3.61 (s. $3 \mathrm{H}), 4.50$ (q. $1 \mathrm{H}), 6.34$ (s. $2 \mathrm{H}) .6 .64$ (d. $2 \mathrm{H}, J=7.7 \mathrm{~Hz}$ ). 6.94 (d. $2 \mathrm{H} . J=7.7 \mathrm{~Hz}) .7 .05$ (d. $2 \mathrm{H} . J=7.9 \mathrm{~Hz}) .7 .25$ (d. $1 \mathrm{H} . J=8.5 \mathrm{~Hz}) .7 .55(\mathrm{~d} .1 \mathrm{H} . J=$ $8.4 \mathrm{~Hz}) .7 .61(\mathrm{~d} .2 \mathrm{H}, J=7.9 \mathrm{~Hz}) .8 .66(\mathrm{~d} .1 \mathrm{H} . J=7.4 \mathrm{~Hz})$. 9.19 (s. $1 \mathrm{H}) .10 .78$ (s. $1 \mathrm{H})$ : Mass me $505(\mathrm{M}+1)$ : Anal. $\left(\mathrm{C}_{36} \mathrm{H}_{24} \mathrm{~N}_{4} \mathrm{O}_{5} \mathrm{~S} \cdot \mathrm{H}_{2} \mathrm{O}\right) \mathrm{C} . \mathrm{H} . \mathrm{N} . \mathrm{S}$.
N-[4-[(2-Amino-6-methy]-4-oxo-3,4-dihydroquinazolin5-yl)-sulfanyl]benzoyl]-(S)-3-(3,4-dihydroxyphenyl)alanine methyl ester (IIc). The coupling reaction of benzoic acid 8 $(0.060 \mathrm{~g} .0 .183 \mathrm{mmol})$ and $(5)$-3-(3.4-dihỵdroxyphenyl)alanine methyl ester $(0.039 \mathrm{~g} .0 .185 \mathrm{~mm} o \mathrm{l})$ was performed as in Method $\mathbf{A}$ and IIc was obtained as a solid $(0.017 \mathrm{~g}$. 18\%): mp 176.5-177.5 ${ }^{\circ} \mathrm{C}:{ }^{1} \mathrm{H}$ NMR (DMSO-d 6 ) $\delta 2.28$ (s. $3 \mathrm{H}), 2.94(\mathrm{~m}, 2 \mathrm{H}), 3.60(\mathrm{~s} .3 \mathrm{H}), 4.49(\mathrm{~m}, \mathrm{HH}), 6.30(\mathrm{bs} .2 \mathrm{H})$ 6.50 (d. $1 \mathrm{H}) .6 .57$ (s. $1 \mathrm{H}), 6.61$ (d. $1 \mathrm{H} . J=6.7 \mathrm{~Hz}$ ). 6.93 (d. $2 \mathrm{H} . J=8.5 \mathrm{~Hz}) .7 .12$ (d. $1 \mathrm{H}, J=8.5 \mathrm{~Hz}) .7 .54$ (d. $1 \mathrm{H}, J=8.5$ Hz). 7.61 (d. $2 \mathrm{H} . J=8.5 \mathrm{~Hz}) .8 .59$ (d. $1 \mathrm{H} . J=7.7 \mathrm{~Hz}$ ). 10.76 (bs, 1H): Mass me $521(\mathrm{M}+1)$.

$N$-[4-[(2-Amino-6-methy]-4-oxo-3,4-dihydroquinazolin5-yl)-sulfanyl]benzoyl]-(S)-3-(4-aminophenyl)alanine methyl ester (IId). The coupling reaction of benzoic acid 8 $(0.060 \mathrm{~g} .0 .183 \mathrm{mmol})$ and $(\mathrm{S})$-3-(4-aminophenyl)alanine methyl ester $(0.040 \mathrm{~g} .0 .20 \mathrm{mmol})$ was performed as in Method $\mathbf{A}$, and IId was obtained as a yellow solid $(0.031 \mathrm{~g}$ 33\%): mp 173-174 ${ }^{\circ} \mathrm{C}:{ }^{l} \mathrm{H}$ NMR (DMSO-d 6 ) $\delta 2.29$ (s. 3H), $2.82-2.97$ (m. 2H). 3.60 (s. $3 \mathrm{H}) .4 .43-4.50(\mathrm{~m} .1 \mathrm{H}), 4.84$ (bs. $2 \mathrm{H}$ ). 6.31 (bs. $2 \mathrm{H}$ ). 6.44 (d. $2 \mathrm{H}, J=8.2 \mathrm{~Hz}$ ). 6.90 (d. $2 \mathrm{H} . J=$ $8.4 \mathrm{~Hz}$ ). 6.94 (d. $2 \mathrm{H}, J=8.6 \mathrm{~Hz}$ ). 7.24 (d. $1 \mathrm{H} . J=8.4 \mathrm{~Hz}$ ). 7.55 (d. $1 \mathrm{H} . J=8.5 \mathrm{~Hz}) .7 .61$ (d. $2 \mathrm{H} . J=8.4 \mathrm{~Hz}$ ). 8.58 (d. $\left.1 \mathrm{H}_{.} J=7.7 \mathrm{~Hz}\right)$ : Mass me $504(\mathrm{M}+1)$ : Anal. $\left(\mathrm{C}_{96} \mathrm{H}_{35} \mathrm{~N}_{5} \mathrm{O}_{4} \mathrm{~S}\right)$ C. H. N. O. S.

$N$-[4-[(2-Amino-6-methy]-4-oxo-3,4-dihydroquinazolin5-yl)-sulfanyl]benzoyl]-(S)-tryptophan methyl ester (IIe). The coupling reaction of benzoic acid $8(0.20 \mathrm{~g} .0 .61 \mathrm{mmol})$ and $(S)$-tryptophan methyl ester $\mathrm{HCl}(0.17 \mathrm{~g} .0 .67 \mathrm{mmol})$ was performed as in Method $A$. and IIe was obtained as a yellow solid $(0.090$ g. $29 \%)$ : mp $171-173^{\circ} \mathrm{C}$ : IR (KBr)

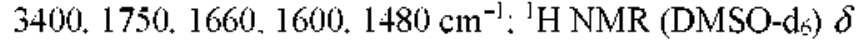
$2.28(\mathrm{~s} .3 \mathrm{H}) .3 .21(\mathrm{~m} .2 \mathrm{H}) .3 .61$ (s. $3 \mathrm{H}), 4.63$ (q. $1 \mathrm{H}), 6.35$ (s. $2 \mathrm{H}) .6 .93$ (d. $2 \mathrm{H} . J=8.5 \mathrm{~Hz}) .6 .97$ (t. $1 \mathrm{H}) .7 .05$ (t. $1 \mathrm{H}) .7 .18$ (d. $1 \mathrm{H}, J=2.1 \mathrm{~Hz}$ ). 7.24 (d. $1 \mathrm{H} . J=8.4 \mathrm{~Hz}$ ). 7.32 (d. $1 \mathrm{H}, J=$ $7.9 \mathrm{~Hz}) .7 .53$ (d. 1H). 7.55 (d. $1 \mathrm{H} . J=8.5 \mathrm{~Hz}) .7 .63$ (d. $2 \mathrm{H} . J$ $=8.4 \mathrm{~Hz}) .8 .68(\mathrm{~d} .1 \mathrm{H} . J=7.5 \mathrm{~Hz})$ : Mass me $528(\mathrm{M}+1)$ : Anal. $\left(\mathrm{C}_{28} \mathrm{H}_{25} \mathrm{~N}_{5} \mathrm{O}_{4} \mathrm{~S} \cdot 2.1 \mathrm{H}_{2} \mathrm{O}\right) \mathrm{C} . \mathrm{H} . \mathrm{N} . \mathrm{S}$

3-[N-[4-[(2-Amino-6-methyl-4-oxo-3,4-dihydroquinazolin-5-yl)-sulfanyl]benzoyl]amino]benzoic acid methyl ester (III). The coupling reaction of benzoic acid $8(0.20 \mathrm{~g}$. $0.61 \mathrm{mmol})$ and 3-aminobenzoic acid methyl ester $(0.093 \mathrm{~g}$. 0.62 mmol) was performed as described in Method $\mathbf{A}$ and IIIa was obtained as a solid $(0.105 \mathrm{~g} .37 \%)$ : $\operatorname{mp~} 258-259^{\circ} \mathrm{C}$ : IR (KBr) 3340, 3200,1660, 1570, $1480 \mathrm{~cm}^{-1}$ : ${ }^{l} \mathrm{H}$ NMR (DMSO-d $) \delta 2.27$ (s. 3H). 3.86 (s.3H). 6.57 (s. 2H). 7.01 (d. $2 \mathrm{H} . J=8.5 \mathrm{~Hz}$ ). 7.19 (d. $1 \mathrm{H} . J=8.4 \mathrm{~Hz}$ ). 7.38 (dd. $2 \mathrm{H} . J$ $=8.2 .8 .8 \mathrm{~Hz}) .7 .67$ (d. $1 \mathrm{H} . J=7.8 \mathrm{~Hz}) .7 .79$ (d. $2 \mathrm{H} . J=8.4$ $\mathrm{Hz}$ ). 8.02 (d. $1 \mathrm{H}, J=8.0 \mathrm{~Hz}) .8 .4$ (s. $1 \mathrm{H}), 10.32$ (s. $1 \mathrm{H})$; Mass mie $460\left(\mathrm{M}^{+}\right)$.

3-[N-[4-[(2-Amino-6-methyl-4-oxo-3,4-dihydroquinazolin-5-yl)-sulfanyl]benzoyl]amino|benzoic acid (IIIb). Methyyl ester IIIa $(0.15 \mathrm{~g})$ was hydrolyzed as in Method B. and IIIb was obtained as an off-white solid $(0.149 \mathrm{~g} .95 \%)$ $\operatorname{mp~} 248-249^{\circ} \mathrm{C}$ : IR (KBr) 3350, 1720. 1660, 1560. 1480 $\mathrm{cm}^{-1}$ : ${ }^{1} \mathrm{H}$ NMR (DMSO-d 6 ) $\delta 2.33$ (s. 3H), 6.45 (s. 2H). 7.02 (d. $2 \mathrm{H} . J=8.4 \mathrm{~Hz}$ ) 7.28 (d. $2 \mathrm{H} . J=8.4 \mathrm{~Hz}$ ) 7.45 (t. $1 \mathrm{H})$. 
7.56 (d. $1 \mathrm{H} . J=8.5 \mathrm{~Hz}$ ). 7.66 (d. $1 \mathrm{H} . J=7.8 \mathrm{~Hz}) .7 .80$ (d. $2 \mathrm{H} . J=8.5 \mathrm{~Hz}) .8 .00(\mathrm{~d} .1 \mathrm{H} . J=8.2 \mathrm{~Hz}$ ). 8.39 (s. $1 \mathrm{H}) .10 .31$ (s. $1 \mathrm{H}$ ). 10.99 (bs. 1H). 12.95 (s. 1H). Mass me $446\left(\mathrm{M}^{-}\right)$. Anal. $\left(\mathrm{C}_{3 \hat{3}} \mathrm{H}_{1} \mathrm{~N}_{4} \mathrm{O}_{4} \mathrm{~S} \cdot 2 \mathrm{H}_{2} \mathrm{O}\right)$ C. H. N. S.

Inhibition of $L$. casei TS: Spectrophotometric Assay. TS activity was assayed by steady-state analy'sis against the cofactor $N^{6} N^{10}$-methy lenetetrahydrofolate as a substrate under conditions of saturating dUMP. using a modification of the literature procedure ${ }^{17}$ The assay mixture contained 50 $\mathrm{mM}$ Tris (pH 7.4), $25 \mathrm{mM} \mathrm{MgCl} .7 .5 \mathrm{mM}$ formaldehyde. 1 $\mathrm{mM}$ ethylenediaminetetraacetic acid disodium salt $\left(\mathrm{Na}_{2}-\right.$ EDTA). $75 \mathrm{mM} \beta$-mercaptoethanol. $2.5 \mathrm{mM}$ dUMP. and 3 $\mathrm{mM} N^{5} N^{\mathrm{j}}$-methylenetetrahydrofolate in a final volume of 1 $\mathrm{mL}$. These reactions were either in the absence of inhibitor (control reaction) or in the presence of inhibitor at concentrations ranging from 0.1 to $20 \mu \mathrm{M}$ to calculate $\mathrm{IC}_{\text {Sij }}$. Reactions were started at room temperature by the addition of enz'me and enz'me activity was measured by following the increase in UV absorbance at $340 \mathrm{~nm}$ upon conversion of $N N^{\mathrm{jl}}$-methy lenetetrahydrofolate to dihy'drofolate. $\mathrm{IC}_{S i j}$ values were determined from semilogarithmic plots of inhibitor concentration is UV absorbance at $340 \mathrm{~nm}$ measured at each concentration relative to that of control reaction.

Inhibition of Human TS: Tritium Release Method. TS activity was measured by assaying the tritium released from $\left[5-{ }^{3} \mathrm{H}\right] \mathrm{dUMP}$ by a modified procedure of Lomax and Greenberg. ${ }^{1}$ The composition of the assay mixture was that used in the spectrophotometric assay except for the use of 25 $\mu \mathrm{M}\left[5^{-3} \mathrm{H}\right] \mathrm{dUMP}$ and $300 \mu \mathrm{M} N^{5} \hat{N}^{10}$-methy lenetetrahy folate and for the inclusion of bovine senum albumin at up to $100 \mu \mathrm{g} / \mathrm{mL}$. The inlibitor concentrations were between 0.3 $\mathrm{nM}$ and $100 \mathrm{nM}$. and the final volume for each assay was 0.1 $\mathrm{mL}$. Reactions were run at room temperature by initiating with the addition of enzyme. After $5 \mathrm{~min}$. the reactions were quenched by the addition of charcoal. the mixture centrifuged to remove charcoal on which unreacted $\left[5^{3} \mathrm{H}\right] \mathrm{dUMP}$ was adsorbed. and the supernatant counted to determine the release of tritium. $\mathrm{IC}_{S \mathrm{Si}}$ values were determined from semilogarithmic plots similar to that described above.

Cell Grow th Inhibition Assay. $\mathrm{IC}_{5 i j}$ values for the inhibition of cellular growth were measured using a modification of the MTT ${ }^{19}$ colorimetric assay of Mosmann ${ }^{20}$ using L1210 (mouse lymphocytic leukemia). LY3.7.2C TK/ (mouse lymphoma thymidine kinase deficient). CCRFCEM (human leukemia), and HT-29 (human colon adenocarcinoma). Cells were seeded at 6.000 (LY TK-/-. HT-29) or 10.000 (L1210. CCRF-CEM) cells per well in 96-well plates. and growth was measured over a range of inhibitor concentrations. Culture medium (RPMI-1640) contained 5\% fetal calf senum. $0.5 \%$ dimethylsulfoxide (DMSO) and 50 $\mu \mathrm{g} / \mathrm{mL}$ penicillin or streptonycin. Plates were incubated for 3 days (L1210. LY TK-/-) or 4 days (CCRF-CEM. HT-29) at $37^{\circ} \mathrm{C}$ in a humidified atmosphere containing $5 \% \mathrm{CO}_{2}$ in air. and then treated with MTT for $4 \mathrm{hr}$. Cells were harvested and cell growth was measured spectrophotometrically: The deposited formazan formed from MTT by cells was dissolved in DMSO and absorbance was measured at 540 $\mathrm{nm}$ using microplate reader. $\mathrm{IC}_{5 i j}$ values were determined from semilogarithnic plots similar to that described above.

Acknowledgments. We thank Profs. D. V. Santi (University of California. San Francisco) and I.-Y. Kwak (Pai Chai University. Korea) for the generous gift of human and $L$. casei TS plasniids. respectively, and Prof. H. H. Evans (Case Western Reserve University) for the thankful supply of LY3.7.2C TK-/- cell line.

\section{References and Notes}

1. Santi. D. V. J. Hed. Chem 1980. 23. 103.

2. Johnston. P. G.: Drake. J. C.: Steinberg. S. M.: Allegra. C. J. Bichem. Phomacol 1983. +5.2483.

3. Takemura. Y. Tackman. A. L. dint-Cancer Drugs 1997. 8.3.

4. Walton. M. I.: Gibson, W: Aherne. G. W.: Lawrence. N: Stephens, T. C.; Smith, M. N.: Jackman. A. L. J. Pharmacol. Exp. Ther: 1996, 277, 909

5. Johnston. P. G.: Liang. C. M.: Henry. S.: Chabner. B. A.: Allegra. C. J. Cancer Res: 1991. 51.6668

6. Jackman. A. L.: Kimbell. R.: Browt1. M.: Brunton. L:: Harrap. K. R: Wardleworth, J. M.: Boyle, F. T. Adv. Exp. 1led Biol 1994. 370.185.

7. Jones. T. R; Calvert. A. H.: Jackman. A. L; Brown, S. J.: Jones. M.: Harrap, K. R. Europ. J. Cancer 1981. 17, 11 .

8. Calvert. A. H.: Alison. D. L.: Harland. S. J.: Robinson. B. A.: Jackman. A. L.: Jones. T. R.: Newell. D. R.: Siddik. Z. H.: Wiltshaw. E.: McElwain. T. J.: Smith. I. E.: Harrap. K. R. J. Clim. Oncol $1986, f, 1245$.

9. Newell, D. R.; Alison, D. L.; Calvert, A. H.: Harrap, K. R: Jaman. M.: Jones. T. R:; Manteuffel-Cymborowskia, M: O'Contor. P. Cancer Treat. Rep. 1986. 70.971

10. Marsham. P. R.: Hughes. L. R.: Tachman. A. L.: Hayter. A. T. Oldfield. T.: Wardleworth. J. M.: Bishop. T. A. M.: O'Connor. B. M.; Calvert, A. H. l. Hed Chem 1991. 34. 1594.

11. Hardy. L. W.; Finer-Moore. J. S.; Montfort, W. R.: Jones, M. O. Santi. D. V.: Stroud. R. M. Science 1987, 235, 449.

12. Sikora. E.: Jackmant. A. L.: Newell. D. R.: Calwert. A. H Bichem. Phomacol 1988. 37. 4047.

13. Webber. S. E.: Bleckman. T. M.: Attard. I.: Deal. T. G.: Kathardekar, V.: Welsh, K. M: Webter. S.: Janson, C. A.; Matthews. D. A.; Smith. W. W.: Freer. S. T.; Jordan, S. R. Bacquet. R. J; Howland. E. F.: Booth, C. L. J; Ward, R. W: Hermant1. S. M.: White. J.: Morse. C. A.: Hilliard. J. A.: Bartlett. C. A. J. Med Chen 1993.36.733

14. Webber. S.: Bartlett. C. A.: Boritzki. T. T.: Hilliard. J. A.: Howland. E. F; Johnston, A. L.: Kosa, M: Margosiak, S. A.; Morse. C. A.; Shetty, B. A. Cancer Chemother: Phamacol 1996. 37.509 .

15. Rafi. I.: Taylor. G. A: Balmanno. K.: Calvete. J. A.: Newell. D. R.: Lind. M. J.: Calvert. A. H. Proc. Am. Assoc. Cancer Res 1994. 35.306 .

16. Chakraborty, T. K.: Reddy, G. V: Hussain, K. A. Tetrahedron Lett. $1991,32,7597$

17. Wahba, A. J Friedkin, M. J. Biol. Chem. 1961. 236. PC11.

18. Lomax. M. I. S.: Greetiberg. G. R. J. Biol. Chem. 1967. 242. I09.

19. MTT is 3-(4.5-dimethylthiazol-2-yl)-2.5-diphenyl-2H-tetrazolium bromide.

20. Mosmann. T. J. Inmunol Hethods $1983,65,55$.

21. Still, W. C.: Kahn. M. Mitra, A. J. Org. Chem. 1978, 43.2923. 